\title{
Luteolin attenuates endotoxin-induced uveitis in Lewis rats
}

\author{
Kazutaka KANAI $^{1) *}$, Takuya HATTA ${ }^{1)}$, Sho NAGATA ${ }^{1)}$, Yuichi SUGIURA ${ }^{1)}$, Kazuaki SATO ${ }^{1)}$, Yohei YAMASHITA ${ }^{1)}$, \\ Yuya KIMURA ${ }^{1)}$ and Naoyuki ITOH ${ }^{1)}$ \\ ${ }^{1)}$ Department of Small Animal Internal Medicine I, School of Veterinary Medicine, University of Kitasato, Towada, Aomori 034-8628, Japan
}

(Received 7 March 2016/Accepted 7 April 2016/Published online in J-STAGE 21 April 2016)

ABSTRACT. The aim of the present study was to investigate the efficacy of luteolin on endotoxin-induced uveitis (EIU) in rats. EIU was induced in Lewis rats by subcutaneous injections of lipopolysaccharide (LPS). One hr before the LPS injection, $0.1,1 \mathrm{or} 10 \mathrm{mg} / \mathrm{kg}$ luteolin or $1 \mathrm{mg} / \mathrm{kg}$ prednisolone was intraperitoneally injected. We investigated its effect upon clinical scores, cellular infiltration and protein leakage, as well as on the level of tumor necrosis factor (TNF)- $\alpha$, nitric oxide (NO) and prostaglandin (PG) E2 in the aqueous humor (AqH). Histologic examination and immunohistochemical analysis in the iris-ciliary body (ICB) were performed to determine the expressions

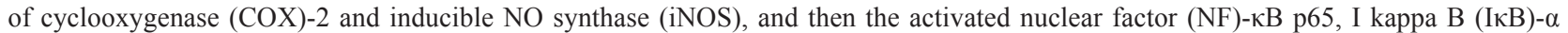
degradation, phosphorylated (p)-IкB kinase (IKK) $\alpha / \beta$ and activator protein (AP)-1 c-Jun. Luteolin suppressed, in a dose-dependent manner, the clinical scores, number of inflammatory cells, the protein concentration, and the TNF- $\alpha$, NO and PGE2 levels in the AqH and improved the histiologic status of the ocular tissue. Luteolin suppressed the expression of iNOS and COX-2 and the activated NF- $\mathrm{kB}$ p65, IкB- $\alpha$ degradation, $\mathrm{p}-\mathrm{IKK} \alpha / \beta$ and AP-1 p-c-Jun in the ICB. The anti-inflammatory potency of $10 \mathrm{mg} / \mathrm{kg}$ luteolin was as strong as that observed with $1 \mathrm{mg} / \mathrm{kg}$ prednisolone. These results demonstrate that luteolin attenuates ocular inflammation by inhibiting expression and release of inflammatory markers, along with the inhibition of the activated NF- $\mathrm{BB}$ pathway and at least partly AP-1 activity in the ICB. KEY WORDS: activator protein 1, anti-inflammatory effect, endotoxin-induced uveitis, luteolin, nuclear factor- $\kappa \mathrm{B}$

doi: 10.1292/jvms.16-0118; J. Vet. Med. Sci. 78(8): 1229-1235, 2016

Endotoxin-induced uveitis (EIU) is a widely established animal model for acute ocular inflammation [27]. This model has applications not only in evaluating the pathophysiology of this condition, but also in investigating new potential treatment [26]. The inflammatory response in EIU is characterized by a breakdown of the blood-barrier and is cellmediated with leakage of protein into the anterior chamber of the eye and infiltration with a large number of polymorphonuclear cells and macrophages in aqueous humor $(\mathrm{AqH})$, and starts $4 \mathrm{hr}$ after LPS injection, with maximum inflammation 18-24 hr after LPS injection [4, 17, 34]. Although the exact mechanism of EIU remains not well understood, evidence indicates that the elevated expressions of inflammatory mediators, including tumor necrosis factor (TNF)- $\alpha$, interleukin (IL)-1 $\beta$, IL-6 [6, 7, 35], nitric oxide (NO) derived from inducible NO synthase (iNOS) [30] and prostaglandin (PG) E2, produced by cyclooxygenase (COX)-2 [2], play pivotal roles in EIU in rats. The expression of inflammatory mediators, such as TNF- $\alpha$, iNOS and COX-2, is controlled by nuclear factor (NF)- $\kappa \mathrm{B}$ and activator protein (AP)-1 [29], as has been shown in various ocular tissues including the iris-ciliary body (ICB) $[13,16,33]$.

$\mathrm{NF}-\kappa \mathrm{B}$ is composed of p65 and p50, while AP-1 is a

\footnotetext{
*Correspondence to: Kanai, K., Department of Small Animal Internal Medicine I, School of Veterinary Medicine, Kitasato University, Towada, Aomori 034-8628, Japan.

e-mail: kanai@vmas.kitasato-u.ac.jp

(C) The Japanese Society of Veterinary Science

This is an open-access article distributed under the terms of the Creative Commons Attribution Non-Commercial No Derivatives (by-nc-nd) License $<$ http://creativecommons.org/licenses/by-nc-nd/4.0/>.
}

ubiquitous protein that resides in the cytoplasm as homo- or heterodimers with the Jun and Fos families. Activation of $\mathrm{NF}-\kappa \mathrm{B}$ and AP-1 is regulated by the phosphorylated p65 and c-Jun, which are subunits of NF- $\kappa \mathrm{B}$ and AP-1, respectively $[14,28]$. The activity of $N F-\kappa B$ is regulated by its interaction with the family of NF- $\kappa \mathrm{B}$ inhibitor protein called I kappa $\mathrm{B}(\mathrm{I} \kappa \mathrm{B})$ which results in the formation of inactive NF- $\kappa \mathrm{B}-$ I $\kappa$ B complexes in the cytoplasm [14]. The I $\kappa B$ kinase (IKK) complex is comprised of IKK $\alpha$, IKK $\beta$ and IKK $\gamma$ or NF- $\kappa B$ essential modulator (MEMO). This multi-protein complexe (c. $700-900 \mathrm{kDa}$ ) is deemed to be the "master coordinator of NF- $\kappa$ B activation' [15].

Luteolin is one of the most common flavonoids present in many dietary foods, including olive oil, broccoli, celery, parsley, green pepper, herb, dandelion and Japanese honeysuckle [20]. Luteolin has served as various molecular targets, such as transcription factors, cytokines, enzymes, apoptosis and growth factors $[5,23]$. NF- $\kappa$ B and AP- 1 inhibiting activities of luteolin have been attributed to anti-inflammatory mechanisms [10, 24, 31].

The purpose of the present study was to examine the effect of luteolin on clinical and histopathologic scores, and inflammatory evaluations in the $\mathrm{AqH}$ and expression of proinflammatory mediators on the ICB in Lewis rat having EIU. In addition, to elucidate the possible mechanism underlying one of anti-inflammatory effects of luteolin, we investigated the activation of NF- $\mathrm{KB}$ pathway and AP-1 activity in the ICB.

\section{MATERIALS AND METHODS}

Animals: Six-week-old male Lewis rats, weighing 
150-170 g, were obtained from SLC (Hamamatsu, Japan) and kept in 12-hr light/12-hr dark cycles for 7 days for acclimatization to the animal house facility. All experiments were performed in compliance with a protocol approved by the Animal Care and Use committee of Kitasato University (approval no. 09-109), and with the Association for Research in Vision and Ophthalmology (ARVO) Statement for the Use of Animals in Ophthalmic and Vision Research.

Antibodies and reagents: Antibodies against iNOS, Cox-2

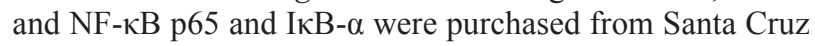
Biotechnology (Santa Cruz, CA, U.S.A.). Phosphorylated (p)-IKK $\alpha / \beta$ and AP-1 p-c-Jun antibodies were purchased from Cell Signaling Technology (Danvers, MA, U.S.A.). Lipopolysaccharide (LPS) from Salmonella Typhimurium and prednisolone were purchased from Sigma-Aldrich (St. Louis, MO, U.S.A.). Luteolin, 3',4',5,7-tetrahydroxyflavone, was purchased from Chroma Dex Inc. (Irvine, CA, U.S.A.).

Induction of EIU and animal groups: After appropriately anesthetized with isoflurane (Dainippon Sumitomo Pharma Co., Ltd., Osaka, Japan), EIU was induced by subcutaneous at two locations of injection of $200 \mu \mathrm{g}$ of LPS (100 $\mu \mathrm{g}$ each subcutaneous) that had been diluted in $0.1 \mathrm{~m} l$ of phosphate-buffered saline (PBS, pH 7.4) [32]. The LPS nontreated animals received the same volume of pyrogen-free PBS subcutaneously (LPS (-) group). Rats were injected intraperitoneally with $0.1,1$ or $10 \mathrm{mg} / \mathrm{kg}$ luteolin in $0.8 \mathrm{ml}$ of PBS containing $0.1 \%$ dimethyl sulfoxide (DMSO, SigmaAldrich). As a positive control, rats were injected intraperitoneally with $1 \mathrm{mg} / \mathrm{kg}$ prednisolone diluted in $0.8 \mathrm{ml}$ of PBS containing $0.1 \%$ DMSO. The intraperitoneal injection was administered $1 \mathrm{hr}$ before LPS injection. Sham animals were not injected by LPS, but only injected intraperitoneally with $0.1 \%$ DMSO in PBS. Each group was comprised of 5, 6 or 8 animals.

Clinical uveitis scoring: Slit lump evaluation was performed $24 \mathrm{hr}$ after LPS injection. The clinical manifestations were recorded and evaluated a left eye by three observers. There was no difference from the evaluation of clinical finding by three observers. Uveitis was graded from scores $0-4$ as previously described [1]. The grading is assigned as: $0=$ no inflammatory reactions; $1=$ discrete dilation of iris and conjunctival vessels; $2=$ moderate dilation of the iris and conjunctival vessels; $3=$ intense iridal hyperemia with flare in anterior chamber; and $4=$ the same clinical signs as 3 plus the presence of fibrinous exudate in the pupillary area with intense flare in the anterior chamber.

Number of infiltrating cells and protein concentrations in AqH: The rats were euthanized $24 \mathrm{hr}$ after LPS injection, and the aqueous humor $(25-30 \mu \mathrm{l} / \mathrm{rat})$ was collected from both eyes per a rat immediately by an anterior chamber puncture using a 30-gauge needle under a surgical microscope (Olympus, Tokyo, Japan). For cell counting, the pooled aqueous humor was suspended in an equal amount of Türk stain solution, and the cells were counted using a hemocytometer under light microscopy. The number of cells per field (an equivalent of $0.1 \mu l$ ) was obtained by averaging the results of four fields from each sample. Then, the aqueous humor samples were centrifuged at $2,500 \mathrm{rpm}$ for $5 \mathrm{~min}$ at $4^{\circ} \mathrm{C}$ to obtain the supernatant. The total protein concentration in the aqueous humor samples was measured with a bicinchoninic acid (BCA) protein assay kit (Pierce, IL, U.S.A.).

$T N F-\alpha, N O$ and PGE2 Levels: The levels of TNF- $\alpha, \mathrm{NO}$ and PGE2 in the AqH were measured by using a total nitrite colorimetric assay (Oxis International, Portland, OR, U.S.A.), TNF- $\alpha$ and PGE2 ELISA kits (R\&D Systems, Minneapolis, MN, U.S.A.) according to the manufacturer's instructions, respectively.

Histopathologic evaluation and immunohistochemistry: Three and $24 \mathrm{hr}$ after LPS injections, both eyes were enucleated and immediately stored in $4 \%$ paraformaldehyde in PBS for $24 \mathrm{hr}$ at $4{ }^{\circ} \mathrm{C}$, and then, the eyes were embedded in paraffin. Sagittal sections ( 3 or $5 \mu \mathrm{m}$ ) were cut and stained with hematoxylin and eosin (HE). Anterior chamber, ICB and vitreous were observed by a masked fashion under light microscopy. The number of infiltrating inflammatory cells surrounding ICB in four sections per left eye, of eight eyes forming different animals, was averaged. Histopathologic evaluation of inflammation was scored by grades of $0-3$ as described previously [12]. In brief, histopathologic evaluation of inflammation was scored by grades of $0-3$. Grade 0 represents no infiltrating cells, grade 1 represents mild cell infiltration (equal to or less than 75, greater than 0 inflammatory cells) and grade 2 represents moderate cell infiltration (equal to or less than 150, greater than 75 inflammatory cells). Grade 3 represents severe cell infiltration with severe anterior chamber exudates (more than 150 inflammatory cells).

Paraffin-embedded serial sections were deparaffinized in xylene, rehydrated through a graded ethanol series and washed with Tris-buffer saline (TBS, pH 7.6). The sections were then boiled in the target retrieval solution buffer $(10 \mathrm{mM}$ citrate buffer solution, $\mathrm{pH}$ 6.0) in autoclave $\left(120^{\circ} \mathrm{C}\right)$ for 5 or $10 \mathrm{~min}$ and left at room temperature for 30 min. Endogenous peroxidase was eliminated by incubation with $0.3 \%$ hydrogen peroxide in methanol for $20 \mathrm{~min}$, then washed in TBS for 5 min three times and incubated in $10 \%$ normal goat serum for $20 \mathrm{~min}$. The sections were incubated with antibodies, iNOS (1:200), COX-2 (1:100), NF-кB p65 (1:200), IкB- $\alpha$ (1:200), p-IKK $\alpha / \beta(1: 150)$ and AP-1 p-c-Jun $(1: 200)$ overnight at $4^{\circ} \mathrm{C}$. They were then stained with peroxidase (Histofine SAB-Po kit; Nichirei, Tokyo, Japan).

Statistical analysis: All data are expressed as mean \pm standard deviation (SD). Parametric data were analyzed by variance (ANOVA), and the Tukey test was used for ad hoc comparison between the two treatment groups. Nonparametric data were analyzed by Kruskal-Wallis, and the Newman-Keuls test was used for ad hoc comparison between the two treatment groups. $P<0.05$ was considered to be statistically significant.

\section{RESULTS}

Clinical scoring and number of infiltrating cells and protein concentration in AqH: Twenty-four hr after LPS injection, the clinical scoring in the LPS group was $3.66 \pm$ 0.51 . One and $10 \mathrm{mg} / \mathrm{kg}$ luteolin treated groups showed a 
significantly reduced clinical scoring compared with LPS group, and the clinical scoring was $1.83 \pm 0.40$ and $1.16 \pm$ 0.40 , respectively $(P<0.01$, Fig. 1A). The effect of $10 \mathrm{mg} / \mathrm{kg}$ luteolin was almost the same as that for the $1 \mathrm{mg} / \mathrm{kg}$ prednisolone group.

In the LPS group, the number of inflammatory cells in the $\mathrm{AqH} 24 \mathrm{hr}$ after LPS injection was $28.16 \pm 4.88 \times 10^{5}$ cells/ $\mathrm{m} l$. The number of inflammatory cells in the groups treated with $0.1,1$ and $10 \mathrm{mg} / \mathrm{kg}$ luteolin was significantly lower than that in the LPS group, and the number of inflammatory cells was19.41 $\pm 3.39 \times 10^{5}$ cells $/ \mathrm{ml}, 13.33 \pm 3.10 \times 10^{5}$ cells $/ \mathrm{m} l$ and $7.41 \pm 1.82 \times 10^{5}$ cells $/ \mathrm{m} l(P<0.01$, Fig. 1B) The effect of $10 \mathrm{mg} / \mathrm{kg}$ luteolin on the number of infiltrating cells in the AqH was almost the same as that for the $1 \mathrm{mg} / \mathrm{kg}$ prednisolone group. No infiltrating cells were detected in the $\mathrm{AqH}$ of non-LPS injection rats.

The protein concentration in the AqH of the LPS group was $28.50 \pm 2.41 \mathrm{mg} / \mathrm{ml}$. Protein concentrations in the $0.1,1$ and $10 \mathrm{mg} / \mathrm{kg}$ luteolin groups were significantly lower than those in the LPS group, and the concentrations were $23.6 \pm$ $1.80 \mathrm{mg} / \mathrm{ml}, 19.37 \pm 1.99 \mathrm{mg} / \mathrm{m} l$ and $15.15 \pm 1.72 \mathrm{mg} / \mathrm{m} l$ $(P<0.05$, Fig. 1C). The reduction in the protein concentration in the $10 \mathrm{mg} / \mathrm{kg}$ luteolin group was almost the same as that of the $1 \mathrm{mg} / \mathrm{kg}$ prednisolone group.

Histopathologic evaluation: Microscopically, sever uveitis was present in LPS group in the ocular tissue $24 \mathrm{hr}$ after LPS injection. It was characterized by intense cell infiltration in anterior chamber and around and in the ICB. Cell infiltrations predominantly consisted of macrophage and neutrophils. Reductions of cell infiltration were observed in eyes treated with $10 \mathrm{mg} / \mathrm{kg}$ luteolin or prednisolone group compared to the LPS group (Fig. 2A). Further, the histopathological grading in the LPS group was $2.62 \pm 0.51$. The group treated with $10 \mathrm{mg} / \mathrm{kg}$ luteolin showed a significantly lower grading compared with the LPS group, and the grading was $1.50 \pm 0.53$. The effect in the $10 \mathrm{mg} / \mathrm{kg}$ luteolin was almost the same as that of the $1 \mathrm{mg} / \mathrm{kg}$ prednisolone group $(P<0.001$, Fig. 2B).

TNF- $\alpha, N O$ and PGE2 levels in AqH: The TNF- $\alpha$, NO and PGE2 levels were remarkable $24 \mathrm{hr}$ after LPS injection, and their levels were $329.24 \pm 45.4 \mathrm{pg} / \mathrm{ml}, 239.64 \pm$ $20.69 \mu \mathrm{M}$ and 2,214.54 $\pm 297.11 \mathrm{pg} / \mathrm{ml}$, respectively. Prednisolone group significantly reduced the levels of TNF- $\alpha$, NO and PGE2 compared to the LPS group, and their levels were $130.78 \pm 49.2 \mathrm{pg} / \mathrm{ml}, 81.83 \pm 28.26 \mu \mathrm{M}$ and $932.51 \pm$ $446.80 \mathrm{pg} / \mathrm{ml}$, respectively. The effect of $10 \mathrm{mg} / \mathrm{kg}$ luteolin on TNF- $\alpha$, NO and PGE2 levels did not differ significantly from those of $1 \mathrm{mg} / \mathrm{kg}$ prednisolone, and their levels were $126.71 \pm 57.55 \mathrm{pg} / \mathrm{ml}, 105.75 \pm 33.28 \mu \mathrm{M}$ and $1018.46 \pm$ $364.24 \mathrm{pg} / \mathrm{ml}$, respectively. (Fig. 3A, B-C).

Immunohistochemical studies for the expression of $i N O S$ and $C O X-2$ and the activated $N F-\kappa B$ p 65 , I $\kappa B-\alpha$ degradation, $p-I K K \alpha / \beta$ and AP-1 p-c-Jun: The immunoreaction for iNOS and COX-2 protein $24 \mathrm{hr}$ after LPS injection was strongly expressed in the ICB and infiltrating cells. Luteolin inhibited the expression of iNOS as well as COX-2 in the ICB (Fig. 4). Three hr after injection of LPS, no activated NF- $\mathrm{BB}$ p65and Ap-1 p-c-Jun-positive nuclei were found in the ICB of
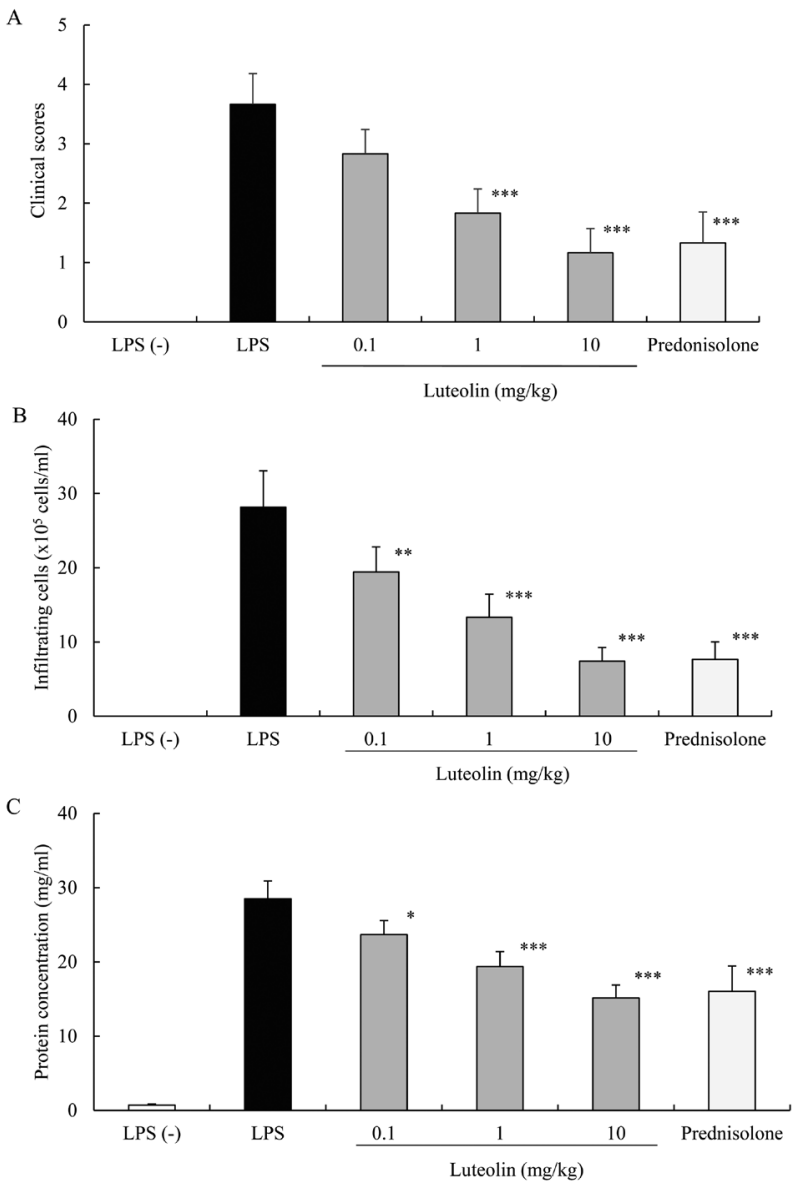

Fig. 1. Effect of luteolin on clinical scores (A), infiltrating cells (B) and protein concentration (C) in aqueous humor $24 \mathrm{hr}$ after LPS injection. Each value represents the mean $\pm \mathrm{SD}(\mathrm{n}=6)$. No clinical signs and infiltrating cells in aqueous humor were investigated from LPS non-treated group (LPS (-) group). $* P<0.05$, $* * P<0.01$ and $* * * P<0.001$, compared with the LPS group.

the LPS (-) group. Activated NF- $\kappa$ B p65 and Ap-1 p-c-Jun immunoreactivity was strongly expressed in the ICB of the LPS group. In contrast, the expression of activated NF- $\kappa B$ p65- and Ap-1 c-Jun-positive cells was inhibited in the ICB of rats treated with $10 \mathrm{mg} / \mathrm{kg}$ luteolin. Luteolin also inhibited I $\kappa$ B- $\alpha$ degradation and $p-I K K \alpha / \beta$ in the ICB (Fig. 5).

\section{DISCUSSION}

In this study, we have demonstrated that luteolin suppressed the clinical score, number of inflammatory cells, the protein concentration, and the TNF- $\alpha, \mathrm{NO}$ and PGE2 levels in the $\mathrm{AqH}$ as well as improved the histiologic status of EIU in a dose-dependent manner. TNF- $\alpha$ may play pivotal roles in the pathogenesis of EIU $[6,25]$. TNF- $\alpha$ expression is demonstrated in intraocular tissues including the ICB in the rat having EIU, and the decreased level of TNF- $\alpha$ in AqH corresponded to the inhibited TNF- $\alpha$ expression in intraocular tissues of the rat with EIU [32]. Symptoms of Behçet's disease 
A

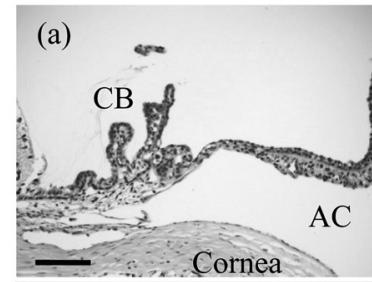

(c)

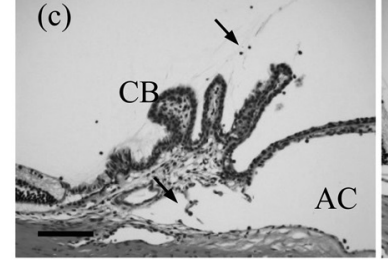

B

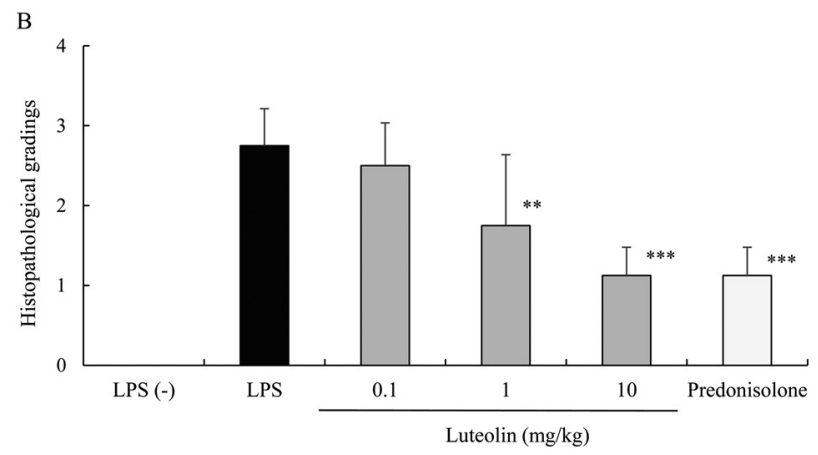

Fig. 2. Histologic evaluation of EIU treated with luteolin. A: histologic changes in the anterior segment of the eye in an animal 24 $\mathrm{hr}$ after LPS injection. Rats without LPS injection (a) showed no inflammation (LPS (-) group). Severe inflammatory cell infiltration was observed in the LPS injected rats (b). A reduction in inflammation was observed in the anterior segment of rats treated with $10 \mathrm{mg} / \mathrm{kg}$ luteolin (c) and $1 \mathrm{mg} / \mathrm{kg}$ prednisolone (d). AC: anterior chamber; CB: ciliary body; HE staining; Bars: $100 \mu \mathrm{m}$; Arrows: inflammatory cells. B: effect of various luteolin dosages on histologic grading of EIU. Each value represents the mean $\pm \mathrm{SD}(\mathrm{n}=8)$. $* * P<0.01$ and $* * * P<0.001$, compared with the LPS group.

were reportedly remarkably ameliorated by administration of anti-TNF- $\alpha$ antibody [21]. Furthermore, the prominent and crucial role of TNF- $\alpha$ has been further shown by diminished inflammation in a TNF- $\alpha$ receptor-deficient model in immune complex-induced uveitis [3]. These, together with NO derived from iNOS and PGE2 produced by COX-2, play important roles in EIU [2].

The iNOS inhibitor, NG-nitro-L-argine (L-NAME), inhibits the development of EIU by inhibiting iNOS activity [18]. COX-2 is responsible for the production of great amount of pro-inflammatory PGs at inflammatory sites in animals and human with inflammatory diseases [19]. ICB is one of the major sources of NO and PGE2 production as well as inflammatory cells and plays a key role in the pathogenesis of EIU $[8,9]$. Our results show that the luteolin attenuated the expression of iNOS and COX-2 in the ICB, suggesting that blocking the expression of iNOS and COX-2 is one of the anti-inflammatory mechanisms of luteolin. Luteolin inhibits
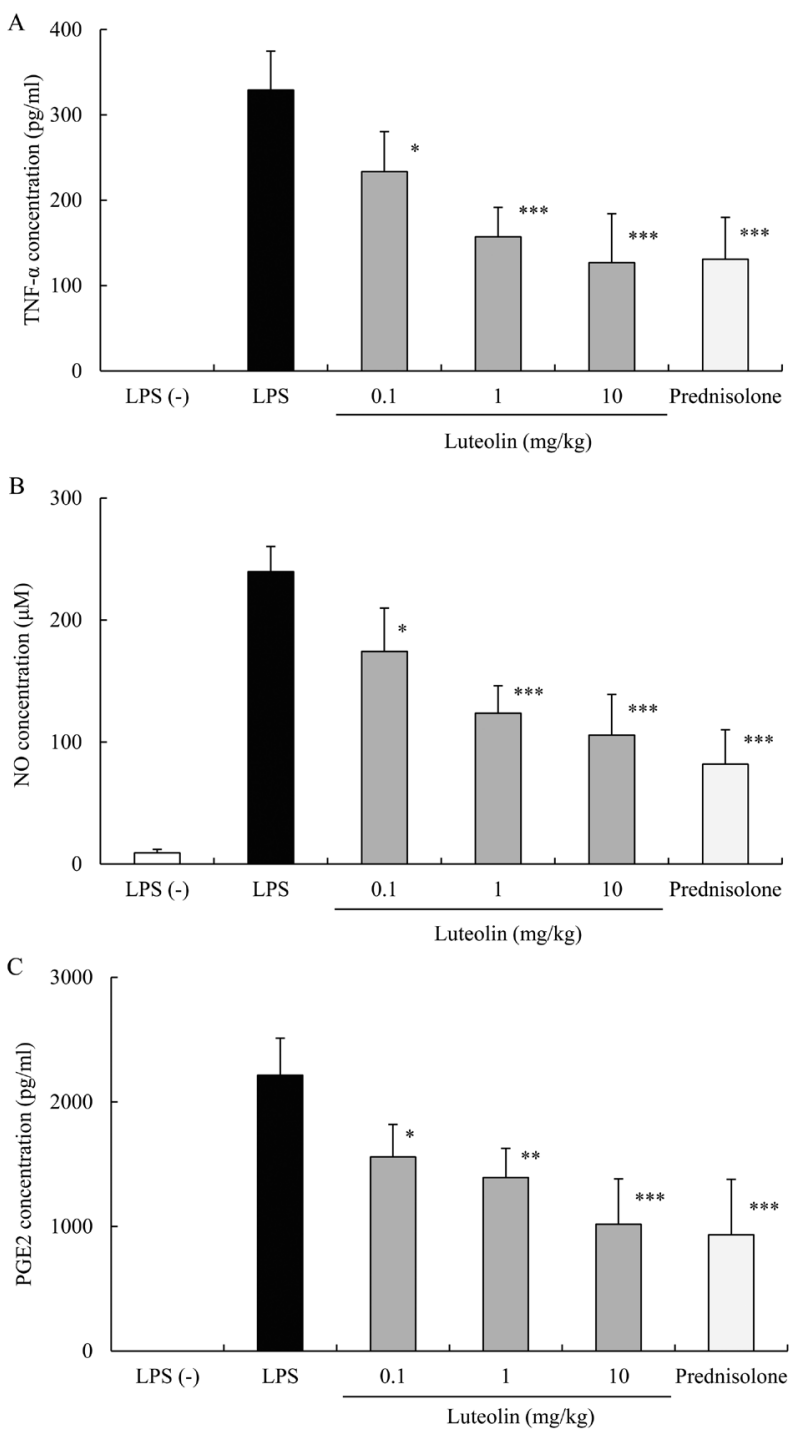

Fig. 3. Effect of luteolin on TNF- $\alpha$ (A), NO (B) and PGE2 (C) levels in the aqueous humor. The aqueous humor was collected $24 \mathrm{hr}$ after LPS injection. Each value represents the mean $\pm \mathrm{SD}$ $(\mathrm{n}=5)$. $* P<0.05, * * P<0.01$ and $* * * P<0.001$, compared with the LPS group.

NF- $\kappa \mathrm{B}$ and AP-1 activation through LPS-induced protein kinase $\mathrm{B}$ (Akt), IKK phosphorylation and I $\mathrm{B}-\alpha$ degradation, as well as reactive oxygen species (ROS) production and then decreased the expression of inflammatory regulating gene products, such as TNF- $\alpha$, IL- 6 , iNOS and COX-2, in vitro and in vivo $[5,10]$. It has been also demonstrated that LPS-induced NF- $\kappa \mathrm{B}$ and AP-1 DNA binding complexes are down-regulated by luteolin in mouse alveolar macrophage [5]. Several reports have shown that the inhibitors of NF-кB and AP-1 successfully prevented uveitis in rats $[11,12,22$, 23]. Consistent with findings of previous studies, we for the first time indicated that luteolin inhibits $\mathrm{p}-\mathrm{IKK} \alpha / \beta$ and I $\mathrm{I} B-\alpha$ degradation and then reduces migration of NF- $\mathrm{\kappa B}$ p65 and 


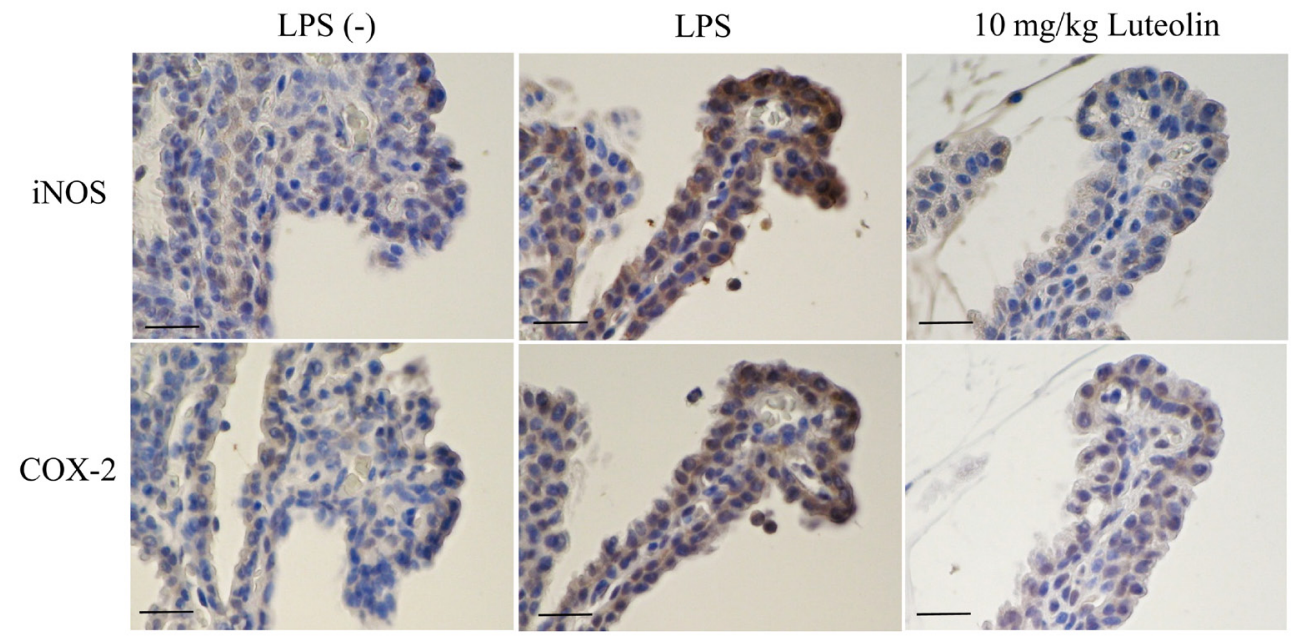

Fig. 4. Effects of luteolin on expression of iNOS and COX-2 in the ICB. Paraffin-embedded serial sections 24 hr after LPS injection were immunostained with antibodies against iNOS and COX-2. Luteolin prevented the expression of iNOS and COX-2 in the ICB. Bars: $25 \mu \mathrm{m}$.

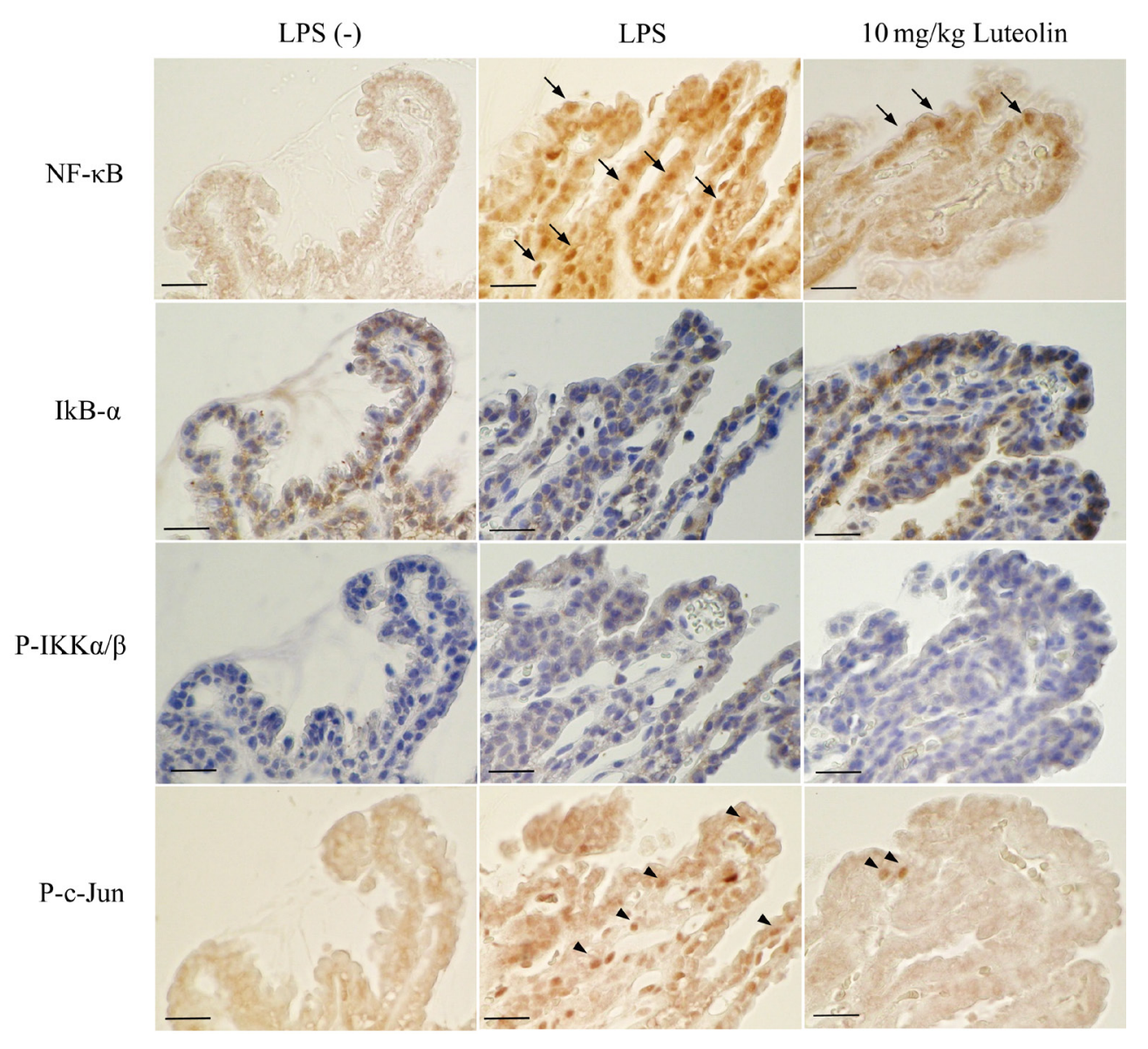

Fig. 5. Effects of luteolin on NF-kB pathway and AP-1activity in the ICB. Serial sections of paraformaldehyde in PBS fixed

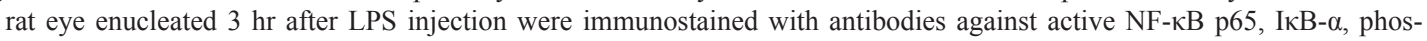
phorylation of IKK $\alpha / \beta$ and AP-1 c-Jun, respectively. Luteolin inhibited the expression of activated NF- $\mathrm{KB}$ p65- and Ap-1 p-c-Jun-positive cells in the ICB. Luteolin inhibited IкB- $\alpha$ degradation and phosphorylation of IKK $\alpha / \beta$. Bars: $25 \mu \mathrm{m}$. Arrows: activated NF-кB p65 positive cells. Arrowheads: phosphorylation of AP-1 c-Jun positive cells. 
AP-1 p-c-Jun from the cytoplasm to the nucleus in the ICB, suggesting a reduction in NF- $\kappa \mathrm{B}$ and $\mathrm{AP}-1$ transcriptional activity. Thus, one of possible mechanisms for the inhibition of iNOS and COX-2 expression in the ICB and TNF- $\alpha$ levels in the $\mathrm{AqH}$ by luteolin treatment could be the inhibition of LPS-induced NF- $\kappa$ B pathway and AP-1 p-c-Jun activation.

In the present study, because luteolin was administered $1 \mathrm{hr}$ before LPS injection, we demonstrated preventive anti-inflammatory effects on EIU. The preventive antiinflammatory potency of $10 \mathrm{mg} / \mathrm{kg}$ luteolin was as strong as that observed with $1 \mathrm{mg} / \mathrm{kg}$ prednisolone. To investigate therapeutic anti-inflammatory effects, we plan to conduct further experiments of EIU treated with luteolin after $4 \mathrm{hr}$ LPS injection.

In conclusion, the present study suggests that luteolin attenuates ocular inflammation by inhibiting the expression and release of inflammatory mediators, along with the inhibition of the activated NF- $\kappa$ B pathway and at least partly AP-1 activity in the ICB. Luteolin may be a promising drug target for the development of ocular anti-inflammatory agents.

ACKNOWLEDGMENT. This study was supported in part by a Kitasato University Research Grant for Scientific Research (No. 2948).

\section{REFERENCES}

1. Behar-Cohen, F. F., Savoldelli, M., Parel, J. M., Goureau, O., Thillaye-Goldenberg, B., Courtois, Y., Pouliquen, Y. and de Kozak, Y. 1998. Reduction of corneal edema in endotoxin-induced uveitis after application of L-NAME as nitric oxide synthase inhibitor in rats by iontophoresis. Invest. Ophthalmol. Vis. Sci. 39: 897-904. [Medline]

2. Bellot, J. L., Palmero, M., García-Cabanes, C., Espí, R., Hariton, C. and Orts, A. 1996. Additive effect of nitric oxide and prostaglandin-E2 synthesis inhibitors in endotoxin-induced uveitis in the rabbit. Inflamm. Res. 45: 203-208. [Medline] [CrossRef]

3. Brito, B. E., O'Rourke, L. M., Pan, Y., Anglin, J., Planck, S. R. and Rosenbaum, J. T. 1999. IL-1 and TNF receptor-deficient mice show decreased inflammation in an immune complex model of uveitis. Invest. Ophthalmol. Vis. Sci. 40: 2583-2589. [Medline]

4. Chan, C. C., Tuaillon, N., Li, Q. and Shen, D. F. 2000. Therapeutic applications of antiflammin peptides in experimental ocular inflammation. Ann. N. Y. Acad. Sci. 923: 141-146. [Medline] [CrossRef]

5. Chen, C. Y., Peng, W. H., Tsai, K. D. and Hsu, S. L. 2007. Luteolin suppresses inflammation-associated gene expression by blocking NF-kappaB and AP-1 activation pathway in mouse alveolar macrophages. Life Sci. 81: 1602-1614. [Medline] [CrossRef]

6. de Vos, A. F., van Haren, M. A., Verhagen, C., Hoekzema, R. and Kijlstra, A. 1994. Kinetics of intraocular tumor necrosis factor and interleukin- 6 in endotoxin-induced uveitis in the rat. Invest. Ophthalmol. Vis. Sci. 35: 1100-1106. [Medline]

7. de Vos, A. F., Klaren, V. N. and Kijlstra, A. 1994. Expression of multiple cytokines and IL-1RA in the uvea and retina during endotoxin-induced uveitis in the rat. Invest. Ophthalmol. Vis. Sci. 35: 3873-3883. [Medline]

8. Helbig, H., Kittredge, K. L., Gurley, R. C., Thurau, S. R., Palestine, A. G. and Nussenblatt, R. B. 1990. Endotoxin-induced pro- duction of inflammatory mediators by cultured ciliary epithelial cells. Curr. Eye Res. 9: 501-505. [Medline] [CrossRef]

9. Jacquemin, E., de Kozak, Y., Thillaye, B., Courtois, Y. and Goureau, O. 1996. Expression of inducible nitric oxide synthase in the eye from endotoxin-induced uveitis rats. Invest. Ophthalmol. Vis. Sci. 37: 1187-1196. [Medline]

10. Jia, Z., Nallasamy, P., Liu, D., Shah, H., Li, J. Z., Chitrakar, R., Si, H., McCormick, J., Zhu, H., Zhen, W. and Li, Y. 2015. Luteolin protects against vascular inflammation in mice and TNF-alpha-induced monocyte adhesion to endothelial cells via suppressing $\mathrm{IKB} \alpha / \mathrm{NF}-\kappa \mathrm{B}$ signaling pathway. J. Nutr. Biochem. 26: 293-302. [Medline] [CrossRef]

11. Jin, X. H., Ohgami, K., Shiratori, K., Suzuki, Y., Hirano, T., Koyama, Y., Yoshida, K., Ilieva, I., Iseki, K. and Ohno, S. 2006. Inhibitory effects of lutein on endotoxin-induced uveitis in Lewis rats. Invest. Ophthalmol. Vis. Sci. 47: 2562-2568. [Medline] [CrossRef]

12. Kanai, K., Ito, Y., Nagai, N., Itoh, N., Hori, Y., Chikazawa, S., Hoshi, F. and Higuchi, S. 2012. Effects of instillation of eyedrops containing disulfiram and hydroxypropyl- $\beta$-cyclodextrin inclusion complex on endotoxin-induced uveitis in rats. Curr. Eye Res. 37: 124-131. [Medline] [CrossRef]

13. Kanai, K., Itoh, N., Yoshioka, K., Yonezawa, T., Ikadai, H., Hori, Y., Ito, Y., Nagai, N., Chikazawa, S., Hoshi, F. and Higuchi, S. 2010. Inhibitory effects of oral disulfiram on endotoxin-induced uveitis in rats. Curr. Eye Res. 35: 892-899. [Medline] [CrossRef]

14. Karin, M. and Ben-Neriah, Y. 2000. Phosphorylation meets ubiquitination: the control of NF-[kappa]B activity. Annu. Rev. Immunol. 18: 621-663. [Medline] [CrossRef]

15. Krappmann, D., Hatada, E. N., Tegethoff, S., Li, J., Klippel, A., Giese, K., Baeuerle, P. A. and Scheidereit, C. 2000. The I kappa B kinase (IKK) complex is tripartite and contains IKK gamma but not IKAP as a regular component. J. Biol. Chem. 275: 29779-29787. [Medline] [CrossRef]

16. Kubota, S., Kurihara, T., Mochimaru, H., Satofuka, S., Noda, K., Ozawa, Y., Oike, Y., Ishida, S. and Tsubota, K. 2009. Prevention of ocular inflammation in endotoxin-induced uveitis with resveratrol by inhibiting oxidative damage and nuclear factorkappaB activation. Invest. Ophthalmol. Vis. Sci. 50: 3512-3519. [Medline] [CrossRef]

17. Li, Q., Peng, B., Whitcup, S. M., Jang, S. U. and Chan, C. C. 1995. Endotoxin induced uveitis in the mouse: susceptibility and genetic control. Exp. Eye Res. 61: 629-632. [Medline] [CrossRef]

18. Mandai, M., Yoshimura, N., Yoshida, M., Iwaki, M. and Honda, Y. 1994. The role of nitric oxide synthase in endotoxin-induced uveitis: effects of NG-nitro L-arginine. Invest. Ophthalmol. Vis. Sci. 35: 3673-3680. [Medline]

19. Masferrer, J. L., Zweifel, B. S., Manning, P. T., Hauser, S. D., Leahy, K. M., Smith, W. G., Isakson, P. C. and Seibert, K. 1994. Selective inhibition of inducible cyclooxygenase 2 in vivo is antiinflammatory and nonulcerogenic. Proc. Natl. Acad. Sci. U.S.A. 91: 3228-3232. [Medline] [CrossRef]

20. Nabavi, S. F., Braidy, N., Gortzi, O., Sobarzo-Sanchez, E., Daglia, M., Skalicka-Woźniak, K. and Nabavi, S. M. 2015. Luteolin as an anti-inflammatory and neuroprotective agent: A brief review. Brain Res. Bull. 119 Pt A: 1-11. [Medline] [CrossRef]

21. Nakamura, S. and Ohno, S. 2005. Anti-tumor necrosis factor alpha antibody in the treatment of Behçet's disease. Int. Ophthalmol. Clin. 45: 179-189. [Medline] [CrossRef]

22. Ohta, K., Nakayama, K., Kurokawa, T., Kikuchi, T. and Yoshimura, N. 2002. Inhibitory effects of pyrrolidine dithio- 
carbamate on endotoxin-induced uveitis in Lewis rats. Invest. Ophthalmol. Vis. Sci. 43: 744-750. [Medline]

23. Pandurangan, A. K. and Esa, N. M. 2014. Luteolin, a bioflavonoid inhibits colorectal cancer through modulation of multiple signaling pathways: a review. Asian Pac. J. Cancer Prev. 15: 5501-5508. [Medline] [CrossRef]

24. Park, C. M. and Song, Y. S. 2013. Luteolin and luteolin-7-Oglucoside inhibit lipopolysaccharide-induced inflammatory responses through modulation of NF-KB/AP-1/PI3K-Akt signaling cascades in RAW 264.7 cells. Nutr. Res. Pract. 7: 423-429. [Medline] [CrossRef]

25. Planck, S. R., Huang, X. N., Robertson, J. E. and Rosenbaum, J. T. 1994. Cytokine mRNA levels in rat ocular tissues after systemic endotoxin treatment. Invest. Ophthalmol. Vis. Sci. 35: 924-930. [Medline]

26. Rosenbaum, J. T. 1989. Uveitis. An internist's view. Arch. Intern. Med. 149: 1173-1176. [Medline] [CrossRef]

27. Rosenbaum, J. T., McDevitt, H. O., Guss, R. B. and Egbert, P. R. 1980. Endotoxin-induced uveitis in rats as a model for human disease. Nature 286: 611-613. [Medline] [CrossRef]

28. Surh, Y. J. 2003. Cancer chemoprevention with dietary phytochemicals. Nat. Rev. Cancer 3: 768-780. [Medline] [CrossRef]

29. Surh, Y. J., Chun, K. S., Cha, H. H., Han, S. S., Keum, Y. S., Park, K. K. and Lee, S. S. 2001. Molecular mechanisms underlying chemopreventive activities of anti-inflammatory phytochemicals: down-regulation of COX-2 and iNOS through suppression of NF-kappa B activation. Mutat. Res. 480-481:
243-268. [Medline] [CrossRef]

30. Toguri, J. T., Lehmann, C., Laprairie, R. B., Szczesniak, A. M., Zhou, J., Denovan-Wright, E. M. and Kelly, M. E. 2014. Antiinflammatory effects of cannabinoid $\mathrm{CB}(2)$ receptor activation in endotoxin-induced uveitis. Br. J. Pharmacol. 171: 1448-1461. [Medline] [CrossRef]

31. Xagorari, A., Papapetropoulos, A., Mauromatis, A., Economou, M., Fotsis, T. and Roussos, C. 2001. Luteolin inhibits an endotoxin-stimulated phosphorylation cascade and proinflammatory cytokine production in macrophages. J. Pharmacol. Exp. Ther. 296: 181-187. [Medline]

32. Yadav, U. C., Srivastava, S. K. and Ramana, K. V. 2007. Aldose reductase inhibition prevents endotoxin-induced uveitis in rats. Invest. Ophthalmol. Vis. Sci. 48: 4634-4642. [Medline] [CrossRef]

33. Yadav, U. C., Subramanyam, S. and Ramana, K. V. 2009. Prevention of endotoxin-induced uveitis in rats by benfotiamine, a lipophilic analogue of vitamin B1. Invest. Ophthalmol. Vis. Sci. 50: 2276-2282. [Medline] [CrossRef]

34. Yang, P., de Vos, A. F. and Kijlstra, A. 1996. Macrophages in the retina of normal Lewis rats and their dynamics after injection of lipopolysaccharide. Invest. Ophthalmol. Vis. Sci. 37: 77-85. [Medline]

35. Yoshida, M., Yoshimura, N., Hangai, M., Tanihara, H. and Honda, Y. 1994. Interleukin-1 $\alpha$, interleukin-1 $\beta$, and tumor necrosis factor gene expression in endotoxin-induced uveitis. Invest. Ophthalmol. Vis. Sci. 35: 1107-1113. [Medline] 